\title{
ACCENT RETRACTION AND TONOGENESIS
}

\author{
FREDERIK KORTLANDT
}

Like its predecessor in Zagreb, the conference on Balto-Slavic accentology in Copenhagen was a great success. The enthusiasm of the organizers Adam Hyllested and Thomas Olander proved highly effective in stimulating discussion among the participants. While in Zagreb most papers dealt with Slavic data, in Copenhagen the emphasis was on Balto-Slavic problems.

Over thirty years ago I formulated my Late Balto-Slavic retraction of the stress from final open syllables of disyllabic word forms unless the preceding syllable was closed by an obstruent (1975: 5f., 1989a: 45, 2005: 154f.), e.g. Lith. gen.sg. vilko 'wolf, dat.sg. viľkui, gálvai 'head', nẽša 'carries', Serbo-Croatian vûka, vûku, glâvi, nëse 'carried', neuter pîlo 'drank', but Lith. gen.sg. aviẽs, gen.pl. vilkũ $<^{\star}$-òm, nom.sg. galvà $<^{*}$-àH, Russian pilá 'she drank' ${ }^{*}$-àH, neuter nesló, infinitive nestí, where syllable-final consonants (including word-final laryngeals) prevented the retraction of the stress. Note that the final stress in nesló and nestí cannot be the result of Dybo's law in view of the quantitative difference between Slovak mohol 'could' < * mògla (b) and niesol 'carried' < ${ }^{*}$ neslì (c). Rick Derksen has rightly concluded that this law generated a class of oxytone nouns in stem-final -CCo-, e.g. Lith. -stas, -klas, Slavic -dlo (1995: 166, 1996: 96-128, 229-232). He has returned to the subject at the meeting of the Indogermanische Gesellschaft in Cracow (2004) and at the present conference in Copenhagen. Several papers at this conference have made clear that his findings have not yet become common knowledge.

Both Hirt's law and my retraction of the stress from a final open syllable to a preceding syllable which was not closed by an obstruent disturbed the Early BaltoSlavic accent system where nouns had either fixed stress on the root or alternating stress between the initial and the final syllable of a word form. The origin of this system has been the subject of controversy since the early studies by Saussure and Pedersen up to Olander's dissertation (2006) and Dybo's contribution to the present conference. While I have accepted Pedersen's view that the accent retraction in Lith. acc.sg. dùkteri 'daughter', Greek thugatéra, was a "recul d'un accent qui contrastait avec un autre accent (final) dans le même paradigme, et qui à cause de ce contraste était exagéré et anticipé" (1933: 25), Olander concurs with Saussure's view that it is "difficile de dire le caractère exact qu'aurait cette loi, car il y a des obstacles à la transformer en loi phonétique pure et simple" (1896: $163=1922$ : 533). Having criticized Olander's original views in detail (2006) without offering a solu- 
tion to his problem, I would now like to suggest a possibility which may be acceptable to our neogrammarian colleagues.

There were two mobile accent patterns in Proto-Indo-European, viz. proterodynamic and hysterodynamic (cf. Pedersen 1926: 24f., 1933: 21f., Beekes 1985: 150, 1995: 175ff.). On the basis of the apophonic alternations in the most archaic attested paradigms, we may reconstruct the following accent patterns for Late IndoEuropean. I shall write Rsd for radical stress, rSd for suffixal stress, and rsD for desinential stress and adduce case forms of Vedic sūnús 'son', Old Irish ainm 'name', Greek thugátēr 'daughter', Lith. piemuõ 'shepherd' and Old Norse oxe 'ox' as examples.

\begin{tabular}{|c|c|c|c|c|}
\hline $\begin{array}{l}\text { nom.sg. } \\
\text { acc.sg. } \\
\text { gen.sg. } \\
\text { loc.sg. } \\
\text { dat.sg. } \\
\text { inst.sg. }\end{array}$ & $\begin{array}{l}\text { sūnús } \\
\text { sūnúm } \\
\text { sūnós } \\
\text { sūnáu } \\
\text { sūnáve } \\
\text { sūnúnā }\end{array}$ & $\begin{array}{l}\mathrm{Rsd}^{*}-s \\
\mathrm{Rsd}^{\star}-m \\
\mathrm{rSd}^{*}-s \\
\mathrm{rS}^{\star}-\emptyset \\
\mathrm{rSd}^{\star}-i \\
\mathrm{Rsd}^{\star}-H_{1}\end{array}$ & $\begin{array}{l}\text { ainm } \\
\text { ainm } \\
\text { anmae } \\
\text { ainm }\end{array}$ & $\begin{array}{l}\mathrm{Rs}^{*}-\varnothing \\
\mathrm{Rs}^{*}-\varnothing \\
\mathrm{rSd}^{*}-s \\
\mathrm{rS}^{*}-\varnothing \\
\mathrm{rSd}{ }^{*}-i \\
\mathrm{Rsd}^{*}-H_{1}\end{array}$ \\
\hline $\begin{array}{l}\text { nom.pl. } \\
\text { acc.pl. } \\
\text { gen.pl. } \\
\text { loc.pl. } \\
\text { dat.pl. } \\
\text { inst.pl. }\end{array}$ & $\begin{array}{l}\text { sūnávas } \\
\text { sūnūn } \\
\text { sūnūnām } \\
\text { sūnúșu } \\
\text { sūnúbhyas } \\
\text { sūnúbhis }\end{array}$ & $\begin{array}{l}\mathrm{rSd}^{*}-e s \\
\mathrm{Rsd}^{\star}-n s \\
\mathrm{rsD}^{\star}-o m \\
\mathrm{rsD}^{*}-s u \\
\mathrm{rsD}^{*}-m u s \\
\mathrm{rsD}^{*}-b h i\end{array}$ & $\begin{array}{l}\text { anman } \\
\text { anman } \\
\text { anman } \\
\text { anmanaib }\end{array}$ & $\begin{array}{l}\mathrm{rSd}^{*}-\mathrm{H}_{2} \\
\mathrm{rSd}^{*}-H_{2} \\
\mathrm{rsD}^{*}-o m \\
\mathrm{rsD}^{*}-s u \\
\mathrm{rsD}^{*}-m u s \\
\mathrm{rsD}^{*}-b h i\end{array}$ \\
\hline $\begin{array}{l}\text { nom.sg. } \\
\text { acc.sg. } \\
\text { gen.sg. } \\
\text { loc.sg. } \\
\text { dat.sg. } \\
\text { inst.sg. }\end{array}$ & $\begin{array}{l}\text { thugátēr } \\
\text { thugatéra } \\
\text { thugatrós } \\
\text { thugatrí }\end{array}$ & $\begin{array}{l}\text { piemuõ } \\
\text { píemeni } \\
\text { piemeñs } \\
\text { piemenyjè } \\
\text { píemeniui } \\
\text { píemeniu }\end{array}$ & $\begin{array}{l}\text { oxe } \\
\text { oxa } \\
\text { oxa } \\
\text { oxa }\end{array}$ & $\begin{array}{l}\mathrm{Rs}^{*}-\varnothing \\
\mathrm{rSd}^{\star}-m \\
\mathrm{rsD}^{*}-o s \\
\mathrm{rSd}^{*}-i \\
\mathrm{rsD}^{\star}-e i \\
\mathrm{rsD}^{\star}-e H_{1}\end{array}$ \\
\hline $\begin{array}{l}\text { nom.pl. } \\
\text { acc.pl. } \\
\text { gen.pl. } \\
\text { loc.pl. } \\
\text { dat.pl. } \\
\text { inst.pl. }\end{array}$ & $\begin{array}{l}\text { thugatéres } \\
\text { thugatéras } \\
\text { thugatrō̄n } \\
\text { thugatrási }\end{array}$ & $\begin{array}{l}\text { píemenys } \\
\text { píemenis } \\
\text { piemenũ } \\
\text { piemenysè } \\
\text { piemenims } \\
\text { piemenimis }\end{array}$ & $\begin{array}{l}y x n \\
y x n \\
y x n a \\
\text { yxnom }\end{array}$ & $\begin{array}{l}\mathrm{rSd}^{*}-e s \\
\mathrm{rSd}^{*}-n s \\
\mathrm{rsD}^{*}-o m \\
\mathrm{rsD}^{*}-s u \\
\mathrm{rsD}^{*}-m u s \\
\mathrm{rsD}^{*}-b h i\end{array}$ \\
\hline
\end{tabular}

Since the radical stress in the nom.sg. form of the hysterodynamic paradigm was isolated, its transfer to the final syllable is a logical development, e.g. Lith. dukte $\tilde{e}$, Vedic duhitâ. The same development could then take place in the sigmatic nom.sg. 
form of the proterodynamic paradigm so as to yield a clear distinction between end-stressed masculines and feminines on the one hand and root-stressed neuters on the other. For the oblique plural cases, which have both radical and suffixal zero grade in the archaic paradigms, I assume final stress in all forms. Medial stress was now limited to the dat.sg. and nom.pl. forms of the proterodynamic paradigm and the acc.loc.sg. and nom.acc.pl. forms of the hysterodynamic paradigm. At this stage, a retraction of the stress in these forms yielded the accent patterns reconstructed for Early Balto-Slavic. This account differs from my earlier treatment (1989a: 43, 2006: 359) in the following respects:

1. There is no need to assume that Indo-European accentual mobility was lost at an early stage. The rise of final stress in Lith. duktẽe, piemuõ, sūnùs is independently motivated by the elimination of radical stress in the hysterodynamic paradigm and generalization of final stress in the non-neuter nom.sg. form.

2. The retraction of the stress from medial syllables (Pedersen's law) may have been a phonetic development, see below.

3. The barytonesis did not affect acc.sg. ãvi 'sheep', sünų 'son', which had preserved Indo-European radical stress, nor żiẽma 'winter', which was built on the original nom.sg. form * gheim (cf. Beekes 1985: 44), but did yield the retraction in diẽva 'god', cf. Vedic devám, because the $o$-stems had fixed stress from the outset.

4. The oxytonesis did not affect inst.sg. sūnumi, inst.pl. žiemomis because the original form in ${ }^{*}$-bhi had final stress already in Indo-European times. There may have been no Balto-Slavic process of oxytonesis at all.

Holger Pedersen stated about the retraction in dukteri: "Il ne s'agit pas d'une loi qui exige le recul de l'accent de toute pénultième; il serait tout à fait impossible de prouver qu'une telle loi se soit jamais manifestée" (1933: 25). I would suggest that Vladimir Dybo's contribution to the present conference points the way to precisely such a solution. Dybo shows that the class of Balto-Slavic oxytone neuters in -CCoidentified by Derksen belong to a.p. (2) in Lithuanian and to a.p. (b) in Slavic with loss of an original acute in the root, e.g. Lith. aũkštas 'floor', tiñklas 'net', Polish $\dot{z}$ adto 'sting', while a subclass with preserved acute belong to a.p. (1) and (a), e.g. Lith. irklas 'oar', Polish mydło 'soap'. The latter evidently originated from Hirt's law whereas the former escaped the Late Balto-Slavic retraction of the stress as a result of the intervening consonant cluster. The metatonical type became productive, e.g. Lith. klõstai 'planked footway', mõstas 'gesture', dé klas 'holster', Polish stadło 'pair', then also Lith. klõtai 'planked footway', stõtas 'build', with -tas for -stas on the analogy of such instances as graũžtas 'core' where the -s- was lost. The metatony resulted from the East Baltic retraction of the stress from final ${ }^{*}$-a established by Derksen (1996: 103, 126, 230f.). The independent loss of the pretonic acute in Early Slavic belongs to my stage 5.3 (1989a: 46). Here the end-stressed neuters es- 
caped the shortening of pretonic long vowels at my stage 7.13 (1989a: 51), evidently because the accent had been retracted analogically at that time. For a recent parallel of such an analogical retraction to a preceding long vowel cf. Štokavian trésèmo 'we shake' beside pečémo 'we bake', where the original stress is preserved in Čakavian tresemò, pečemò.

Derksen's end-stressed neuters can also be found among polysyllabic formations, e.g. Lith. kabỹklas or kabyklà (2) 'peg', kratỹklas or kratỹklè 'shaker', where the metatony evidently originated from the East Baltic retraction of the stress from final *à. This is the explanation of Dybo's "dominant" suffixes with concomitant metatony on the preceding syllable. More generally, such nouns as aviniñkas 'sheepfold', dalỹkas 'object', degùtas 'tar', malũ̃nas 'mill', sidãbras 'silver', vainikas 'garland', žmogystà (2) 'person', gyvatà (2) 'life', lydekà (2) 'pike' and diminutives in -ùkas (cf. Stang 1957: 12) represent original end-stressed thematic neuters. Substantives with metatony derived from otherwise identical adjectives also belong here, e.g. naujõkas 'novice', pagiréika 'boaster', cf. naujókas 'pretty new', prieštariẽkas 'disputatious person'. In Slavic the end-stressed neuters are represented by abstracts in -stvo and diminutives in -bc- (cf. Dybo 1968: 174-192, 1981: 146-172).

Beside the end-stressed neuters there is a second class of formations which yielded "dominant" suffixes with concomitant metatony in East Baltic, e.g. Lith. $-\tilde{y} b \dot{e},-\tilde{y} s t \dot{e}$ (cf. Derksen 1996: 181, 188). Here the accent was retracted from a prevocalic ${ }^{*} i$ (cf. already Stang 1966: 167, Kortlandt 1977: 324). Other examples of this retraction are vandẽnis 'water-', auksinis 'gold-', vyriškis 'man', jaunikis 'bridegroom', maniškis 'my', drabǔžis 'clothing', melãgis 'liar'. This type cannot represent *-iàs, which is found in gaidỹs 'rooster', gen.sg. gaĩdžio, cf. Estonian takijas from Lith. degỹs 'thistle', Latv. dadzis, but must be compared with Lith. vilke 'she-wolf < ${ }^{*}$ wilkiH-aH, Russ. volčíca < ${ }^{\star}$ wilkiH-kaH, Vedic vrkī̄ $<{ }^{*}$ wlkíHs, gen.sg. vṛkías < ${ }^{*}$ wlkiHós. The accent was not retracted from Lith. -tùvas, -tùve $<{ }^{*}$-tuH-, Russ. žratvá 'grub', which represents the same type (cf. Kortlandt 1997: 162 on these formations). In Slavic the type is attested in abstracts and collectives in -rje and -rja and in possessive adjectives in -bj- (cf. Dybo 1968: 181-191, 1981: 152-170). Interestingly, the possessive adjective replaces the genitive in the oldest Slavic texts (cf. Vaillant 1977: 52, Kortlandt 1978: 294f.), e.g. synz božii 'son of God', which allows the identification of $-b j-<^{*}-i H$ - with the Italo-Celtic gen.sg. ending $-\bar{i}$. I conclude that all "dominant" suffixes of the second class can be derived from formations in ${ }^{*}-i H,{ }^{*}-u H$.

There is a third class of "dominant" suffixes which originated from Hirt's law, e.g. Lith. taukúotas 'greasy', kraujúotas 'bloody', Russ. ženátyj 'married', bludníca 'fornicatress', travina 'blade' (cf. Dybo 1968: 193-195, 1981: 172-174). It thus appears that all "dominant" suffixes can be derived from Early Balto-Slavic end-stressed forms. It follows that the accent retraction in Lith. dukteri may have been a phonetic development which eliminated the stress from any medial syllable and gave rise to the characteristic accent system where all nouns had either fixed stress on 
the root or alternating stress between the initial and the final syllable of a word form.

The rise of metatony as a result of accent retraction in Lith. vilke 'she-wolf < * wilkiH-aH may be compared with the rise of the independent svarita in Vedic gen.sg. vrkyàs < vrkías. When the $-i$ - lost its syllabicity, it also lost its high tone and the stress shifted to the neighboring syllables, which were less prominent than the earlier stressed syllable but still had a higher tone than other unstressed syllables. This typically gave rise to a new distinctive tone, which resembled the high tone of stressed syllables in being prominent but the low tone of unstressed syllables in not being high. Glottalization was evidently weaker in Lithuanian, where it has largely been lost, than in Latvian, where it is better preserved. As a result, the tonal effect of the accent retraction on the newly stressed syllable was different in the two languages. If glottalization is weak, the tonal rise caused by the increased pressure before the glottal closure lasts longer than the tonal fall caused by the glottal constriction. If glottalization is stronger, the fall is more pronounced than the preceding rise. When the accent was retracted to a preceding glottalized syllable we therefore expect a rising tone in Lithuanian and a falling tone in Latvian, and this is what we find. When the newly stressed syllable was not glottalized, the retraction yielded a rising tone in Latvian because there was no pronounced fall in the syllable but a falling tone in Lithuanian, where the initial part of the syllable was more prominent. In a similar way, Latvian subsequently developed a stretched tone from the rise before the glottal closure in the remaining stressed glottalized syllables but a falling tone when the initial part of the syllable was more prominent. The Aukštaitian dialects of Lithuanian developed a falling tone from the remains of glottalization in stressed syllables and a rising tone where that fall was absent.

The Early Balto-Slavic system of lateral accentual mobility was renewed twice, once in Slavic and once in Lithuanian, e.g. Russ. ná vodu 'onto the water', né byl 'was not', Lith. nèveda 'does not lead', prisimena 'remembers' (cf. Kortlandt 1989a: 49, 1977: 326). Both developments can be viewed as a generalization of unstressed word forms. The problem with this view is that it requires either the presence of an immediately preceding stressed word form, as in Lith. prisimena, Bulg. Čérno more 'Black Sea', or the presence of distinctive tone on the initial syllable, as in SCr. nä $v o d u$. In Lithuanian, the generalization of unstressed word forms evidently required the introduction of a high tone on the last prefix at a stage which was more recent than the lengthening of stressed $e, a$, cf. vẽda 'leads'. In Slavic we have to assume the rise of a tonal distinction after the generalization of accentual mobility in the non-acute masculine $o$-stems, which must be dated after Meillet's law (cf. Kortlandt 1989a: 46, 49). Since the distinctive tone appears on the first prefix or preposition in Slavic, we have to accept a retraction of the stress to the initial syllable of the extended word form or phrase. While pre-accentuation is a property of the word in Lithuanian, it is a property of the phrase in Slavic. While the Early Balto-Slavic retraction of the stress in dikteri may have been a phonetic development, the retrac- 
tion in nèveda and Russ. ná vodu originated from generalization of an alternating morphological variant. The rise of a tonal distinction in East Baltic and Slavic has a perfect analogue in the rise of the independent svarita and of extended low tone phrases, respectively, in Vedic Sanskrit.

Here I would like to add a remark on the suffix which is attested as Lith. -ingas, Latv. -îgs, North Slavic -ęn- and South Slavic -ěn-. Following Thurneysen (1883), I assume a development of intervocalic $-n g-<^{*}-n g n-<^{*}-K n$-, where ${ }^{\star} K$ stands for ${ }^{\star} k,{ }^{\star} g,{ }^{\star} g h$ (e.g. 1988: 388, 1989b: 104). The original obstruent could be restored on the basis of cognate forms where it was not followed by the nasal (cf. ibidem). The intermediate stage seems to be preserved in Greek (cf. Allen 1974: 35), Latin (cf. Allen 1970: 23), and Slavic, where the coexistence of -ęn- and -ěn-points to original ${ }^{*}$-ingn- with loss of ${ }^{*}$-g- around stage 7.5 in South Slavic and around stage 7.15 in North Slavic (cf. Kortlandt 1989a: 5of.).

I have little to add on the other contributions to the conference. Mate Kapovic reconstructs both Slavic ja (a) < Indo-European *ég and Slavic jazz (b) < e eǵHóm, cf. Vedic ahám 'I', but lateral mobility (c) in the oblique cases. The geographical distribution of $(j) a z$, which is found in southeastern and northwestern South Slavic and in southwestern and northwestern West Slavic, suggests to me that Slovene jàz (a) is the oldest form and that *já (b) is a Proto-Slavic innovation which did not reach the peripheral dialects. I find it improbable that the two forms coexisted during 4000 years of linguistic development without a clear semantic distinction. Moreover, I reconstruct original fixed stress on the initial syllable of the oblique case forms (b), as in Vedic Sanskrit.

Tijmen Pronk reconstructs a mobile accent paradigm (c) with final stress in the nom.acc.sg. form for Slovene vréme 'weather', where I assume fixed stress on the suffix as a result of Dybo's law (b) and substitution of ${ }^{\star} e$ for ${ }^{\star} \check{e}$ in the root on the analogy of pléme 'tribe'. Since the full grade suffix of the nom.acc.sg. form was taken from the oblique cases (cf. Kortlandt 1983: 176), the assumption of an accentual difference is highly improbable. I find no evidence for original accentual mobility in the neuter $n$-stems except for the word *ime 'name', where the full grade root vowel of Latin nōmen had been eliminated in Balto-Slavic times already.

Matej Šekli reconstructs a.p. (a) for Beljàk, Čedàd, Kobaríd, Prosníd, Solkàn, Subíd, Sužíd and a.p. (b) for Bregínj, Gumín, Krmín, Tolmín, Bóvec, Ratènj, Tŕst, Áhten, Videm. As Tijmen Pronk remarked at the conference, the accent pattern is evidently based on the timbre of the vowel which was stressed before Dybo's law, viz. acute ${ }^{\star} a$ or ${ }^{*} i$ in a.p. (a) but non-acute ${ }^{*} y,{ }^{*} e,{ }^{*} b$ in a.p. (b).

Steven Young observes that Latvian borrowings from Old Russian have a stretched tone if the original vowel was acute but a falling tone if it was circumflex or pretonic, e.g. miẽsts 'hamlet', muõka 'torment', grãmata 'book' (a), grẹ̀ks 'sin', bẹda 'care', stràdât 'work' (b), svệts 'holy', grẹda 'pile', vèsts 'news' (c). Since the stretched tone reflects stressed glottalization (see above), this distribution suggests that glottalization had been preserved in Russian at the time of borrowing. This 
view is supported by the word kalps 'servant', Russ. xolóp, where the absence of polnoglasie shows that it was borrowed before the loss of glottalization (cf. stages 9.1 and 9.2 of Kortlandt 1989a: 54).

I conclude that we must be grateful to Hyllested and Olander for taking over the initiative and establishing a tradition. There can be no doubt that the new series of conferences on Balto-Slavic accentology has already produced important results and will continue to do so in the years to come.

\section{REFERENCES}

Allen, W. Sidney

$1970 \quad$ Vox Latina. Cambridge: UP.

$1974 \quad$ Vox Graeca. Cambridge: UP.

Beekes, Robert S.P.

1985 The origins of the Indo-European nominal inflection. Innsbruck: IBS.

1995 Comparative Indo-European linguistics: An introduction. Amsterdam-Philadelphia: Benjamins.

Derksen, Rick

1995 On the origin of the Latvian tones. Linguistica Baltica 4, 163-168.

1996 Metatony in Baltic. Amsterdam-Atlanta: Rodopi.

2004 The fate of the neuter 0 -stems in Balto-Slavic. Paper read at the meeting of the Indogermanische Gesellschaft in Cracow, October 2004.

Dybo, Vladimir A.

1968 Akcentologija i slovoobrazovanie v slavjanskom. Slavjanskoe jazykoznanie: VI meždunarodnyj s"ezd slavistov, Praga, 1968, 148-224. Moskva: Nauka.

$1981 \quad$ Slavjanskaja akcentologija. Moskva: Nauka.

Kortlandt, Frederik

1975 Slavic accentuation: A study in relative chronology. Lisse: Peter de Ridder; also www.kortlandt.nl.

1977 Historical laws of Baltic accentuation. Baltistica 13/2, 319-330.

1978 On the history of the genitive plural in Slavic, Baltic, Germanic, and IndoEuropean. Lingua 45, 281-300.

1983 On final syllables in Slavic. Journal of Indo-European Studies 11, 167-185.

1988 Remarks on Winter's law. Studies in Slavic and General Linguistics 11, 387-396.

1989a Od praindoevropskog jezika do slovenskog (fonološki razvoj). Zbornik za Filologiju i Lingvistiku 32/2, 41-58; English edition: From Proto-Indo-European to Slavic, www.kortlandt.nl.

1989b Lachmann's law. The new sound of Indo-European: Essays in phonological reconstruction, 103-105. Berlin: Mouton.

1997 Baltic $\bar{e}$ - and $\bar{\imath} / j \bar{a}$-stems. Baltistica $32 / 2,157-163$.

2005 Holger Pedersen's Études lituaniennes revisited. Baltistica: VI priedas, 151-157.

2006 Balto-Slavic accentual mobility. Baltistica 41/3, 359-369.

Olander, Thomas

2006 Accentual mobility: The prehistory of the Balto-Slavic mobile accent paradigms.

Diss. Copenhagen. 
Pedersen, Holger

1926 La cinquième déclinaison latine. København: Høst.

1933 Études lituaniennes. København: Levin \& Munksgaard.

Saussure, Ferdinand de

1896 Accentuation lituanienne. Indogermanische Forschungen: Anzeiger 6, 157-166.

1922 Recueil des publications scientifiques. Genève: Sonor.

Stang, Christian S.

1957 Slavonic accentuation. Oslo: Universitetsforlaget.

1966 Vergleichende Grammatik der baltischen Sprachen. Oslo: Universitetsforlaget.

Thurneysen, Rudolf

1883 Urspr. $d n, t n, c n$ im lateinischen. Zeitschrift für vergleichende Sprachforschung 26, 301-314.

Vaillant, André

1977

Grammaire comparée des langues slaves 5: La syntaxe. Paris: Klincksieck. 